End to Weston-super-Mare the raised beaches are more or less covered with "Head," which often contains large and undoubtedly ice-borne boulders. Under the raised beaches of the W. coast of Cornwall and Devon, traces of an older deposit with ice-borne boulders may occasionally be seen, as I have been informed by $\mathbf{M r}$. Whitley of Truro, who has had very extensive opportunities of observing these phenomena. The raised beaches themselves sometimes contain very far transported erratics (washed out of an older glacial deposit ?).

In answer to H. E. H., it ought to be remembered that, in Sir H. de la Beche's day, the effects of glacial action were but little understood, and it is probable that he never saw sections of curved laminæ like those which of late years have been exposed by extensive quarrying and mining operations. I would refer $H$. F. H. to the very able defence of the glacial origin of persistently curved laminæ by Mr. Tiddeman in the Q. J. G. S. vol. xxviii. p. 480.

D. MACKiNTOSH.

\title{
ON THE FAUNA AND AGE OF THE SHINETON SHALES.
}

SrR,-I was' glad to see in your April issue a letter by Dr. Linnarsson on the Trilobites of the Shineton Shales, as I am desirous that my conclusions should be tested in every possible way. I have carefully reviewed every detail to which he has suggested exception, and beg to submit a brief reply to his criticisms. His statements are the following.

1. Conocoryphe monile is more nearly related to Angelin's genus Euloma than to Conocoryphe striata.

To this I demur. Euloma is described by Angelin as covered with a smooth crust, and with pleurce acute, and bent back at the ends. C. monile has a granular surface and blunt pleurce. I submit that these are more important characters than the "strongly-lobed glabella and the dotted marginal furrow," in which $C$. monile is supposed to resemble Euloma. C. striata is larger than C. monile, has the glabella more conical, and with a third pair of side furrows, and has the frontal margin undotted, but on the whole the two species are of the same type.

2. Lichapyge is more closely allied to Remopleurides than to Lichas.

To this also I cannot agree. Dr. Linnarsson assumes that in my genns the "two hindermost thoracal segments" are united with the pygidium. If he were to examine my specimen, he would see that it consists of one undivided piece, and is therefore a pygidium only. This being so, it cannot be related to Remopleurides. It resembles Lichas in the number of segments (three), and in the shape of the pleuræ; but differs in the telson, which in Lichas ends in two denticles, while in Lichapyge it forms a broad sword-like blade with a central point.

3. Platypeltis is more nearly related to Niobe than to the typical Asaphi.

I myself called attention to this point on page 659 . 
4. Conophrys is probably the same as Shumardia, Billings, and as Battus pusillus, Sars.

I can say nothing to this, as I have been unable to obtain the published descriptions of the forms referred to.

Dr. Linnarsson seems to infer from the presence of Conocoryphe monile that the Shineton Shales are Upper Tremadoc. Even if his opinion of the affinities of this species were correct, we could not ignore the presence of two species of Olenus, of Dictyonema sociale, and of other Cambrian forms. Nor must we overlook the fact that in the Malvern district the Shales with Dietyonema immediately orerlie the black Olenus Shales. I think that, with our present evidence, it will be safest to correlate the Shineton Shales with the Lower Tremadoc. I have just had the good fortune to detect them in force between the Longmynd and the Stiper Stones, the higher beds forming the base of the Stiper Stones escarpment. The dip is in the same direction as the overlying Arenigs; but towards the top of the series (where it grows more arenaceous and flaggy, as in the Shineton area) the beds are contorted and much jointed. I will not venture upon theory on the strength of one hour's work. It is gratifying to find my previous evidence from fossils so clearly confirmed, and to throw in the teeth of the unbelieving stratigraphists another proof that palæontology is not quite exploded.

WELLINGTON, SALOP, May $9 t h, 1878$.

Charles Caluaway.

ORTHIS REDUX IN MIDLAND BUNTER PEBBLES.

Sir,-In reply to the letter of Mr. J. H. Jennings in the May Number of the Gror. MAG. it may interest him to know that the Rev. P. B. Brodie has drawn attention to the occurrence of fossiliferous pebbles in the drift near Warwick similar to those which occur at Budleigh Salterton, in the Quart. Journ. of the Geol. Soc. of London, vol. xxiii. (1867), p. 210.

The Drift of the Midland Counties is mainly composed of the redistributed Bunter Conglomerate, a formation which, as far as the pebbles which it contains are concerned, is lithologically and palæontologically identical with the Conglomerate of S. Devon. 'The stratigraphical position and relation of the two deposits, so far as I have examined them, in both districts appears much the same.

In the Museum of the Midland Institute is an extensive series of Bunter material, collected from the gravel around Birmingham, which I presented in 1872 to the Birmingham Naturalists' Society, as well as of specimens for purposes of comparison from the Bunter Conglomerate itself. In 1875 I gave a beautiful series of fossiliferous pebbles to the Jermyn Street Museum, also from the Birmingham Drift. Orthis redux is, as at Budleigh, one of the commonest fossils.

Henbory, Bristor, May 11, 1878.

Spencer Grorge Peroeval.

WHAT IS AN ERRATIC?

SrR,-Under this title, in your April Number for the current year, my esteemed colleague, Mr. Wynne, argues that I am wrong in restricting the term to fragments which have been transported by 